\title{
Taxonomic notes on miscellaneous Cruciferae
}

\author{
D. A. German \\ Department of Biodiversity and Plant Systematics, Centre for Organismal Studies, Heidelberg University, \\ Im Neuenheimer Feld 345; D-69120 Heidelberg, Germany; \\ South-Siberian Botanical Garden, Altai State University, Lenin str., 61; 656049, Barnaul, Russia \\ E-mail: oreoloma@rambler.ru
}

Key words: Barbarea, Brassicaceae, Ceriosperma, floristic findings, new combinations and synonyms, systematics, Turkey.

Summary. Taxonomy of miscellaneous taxa of Cruciferae (Brassicaceae) is updated. Six new combinations (Erophila macrosperma, Isatis densiflora, Mostacillastrum volckmannii, Noccaea boissieri, Odontarrhena caliacrae, and Rorippa tsaratananae) are validated. Four names are newly reduced to synonymy of what follows them in parentheses: Barbamine procumbens (Barbarea ketzkhovelii), Cochlearia microcarpa (Rorippa austriaca), Torularia karatavica (Strigosella scorpioides), and Tetracme leptopoda (T. recurvata). One name (Cochlearia microcarpa) is lectotypified. Barbarea ketzkhovelii is recorded for the first time from Turkey. Brief nomenclatural comments are provided for all entries.

\section{Таксономические заметки о различных крестоцветных (Cruciferae)}

\author{
Д. А. Герман \\ Отделение биоразнообразия и систематики растений, Центр исследований организмов, Гейдельбергский университет, \\ Им Нойенхаймер Фельд, 345; D-69120, Гейдельберг, Германия; \\ Южно-Сибирский ботанический сад, Алтайский государственный университет, \\ пр-т Ленина, 61; 656049, Барнаул, Россия
}

Ключевые слова: Brassicaceae, флористические находки, новые комбинации и синонимы, систематика, Турция, Barbarea, Ceriosperma.

Аннотация. Работа посвящена уточнению систематики ряда представителей семейства крестоцветных (Cruciferae, или Brassicaceae). Обнародовано шесть новых комбинаций (Erophila macrosperma, Isatis densiflora, Mostacillastrum volckmannii, Noccaea boissieri, Odontarrhena caliacrae, Rorippa tsaratananae). Названия Barbamine procumbens, Cochlearia microcarpa, Torularia karatavica и Tetracme leptopoda отнесены в синонимы, соответсвенно, к Barbarea ketzkhovelii, Rorippa austriaca, Strigosella scorpioides и Tetracme recurvata. Для Cochlearia microcarpa выбран лектотип. Во флоре Турции впервые отмечена Barbarea ketzkhovelii. Все номенклатурные решения кратко прокомментированы.

Further work on taxonomy of the Cruciferae Juss. (Brassicaceae Burnett) representatives for the project "BrassiBase" (Kiefer et al., 2014) and some others yielded another set of nomenclatural novelties to be published. The present communication continues the series of short notes focused on validating new combinations and establishing new synonyms in various mustard genera (German, 2008, 2014).
It is an honor for me to dedicate this communication, as other articles in this issue, to the memory of Rudolf Vladimirovich Kamelin, one of the leading Soviet/Russian botanists of several last decades, an authority in taxonomy of many plant groups including the mustard family, a founder of Turczaninowia, and - from a personal perspective an experienced companion in several field trips, 
one of the first co-authors, an extremely interesting collocutor, and the teacher.

\section{New combinations}

Erophila macrosperma (Sebald) D. A. German, comb. et stat. nov. $\equiv E$. verna subsp. spathulata var. macrosperma Sebald, 1969, Stuttgarter Beitr. Naturk. 206: 19. $\equiv$ E. verna subsp. macrosperma (Sebald) Jonsell, 2000, Nordic J. Bot. 20(2): 201.

Based on morphological, ecological, geographical, and cytological evidences presented by Sebald (1969) and Jonsell $(1976,2000)$, the plant is apparently the most distinct among other taxa often accepted as "main" subspecies of $E$. verna (L.) Bess. s. 1. (Walters in Heywood, 1964; Schultze-Motel et al., 1986; Walters, 1993; Marhold, 2011) which are not infrequently treated as distinct species (conf. Kalheber, 2003; Raus in Raab-Straube, Raus, 2014) along with some additional recognizable entities of this complex (Bomble, 2012). Under these circumstances a species rank is required for the endemic Ethiopian Erophila DC. (P!, STU!).

Nowadays a general switch to treating Erophila as part of Draba L. is observed (Buttler, Hand, 2008; Koch in Kadereit et al., 2016). However, results of the most detailed phylogenetic study of Draba and related genera (Jordon-Thaden et al., 2010) do not uniquely preclude the contrary approach.

Isatis densiflora (Bunge ex Boiss.) D. A. German, comb. nov. $\equiv$ Pachypterygium densiflorum Bunge ex Boiss., 1867, Fl. Orient. 1: 373.

This taxon is not always accepted as specifically distinct from the polymorphic I. milticaulis (Kar. et Kir.) Jafri although, unlike other ones usually treated conspecific with the latter, it is characterized by both recognizable morphology (dense, short, often secund infructescence) and its own distribution range considerably overlapping with that of I. milticaulis but stretching further south-westward (Boczantzeva, 1985). Therefore, approach of Boczantzeva (1. c.) and a number of previous authors in delimitation of these closely related species is preferred here with the only difference in generic placement accepted in accordance with results of recent studies (Moazzeni et al., 2007, 2010; Al-Shehbaz, 2012a).

Mostacillastrum volckmannii (Phil.) D. A. German et Al-Shehbaz, comb. nov. $\equiv$ Sisymbrium volckmannii Phil., 1872, Anales Univ. Chile 41: 669.

$=$ Mostacillastrum sagittatum (Kuntze) AlShehbaz, 2006, Darwiniana 44(2): 348. $\equiv$ Sisym- brium sagittatum Hook. et Arn., 1833, Bot. Misc. 3: 139, non Ait. (1789). $\equiv$ Hesperis sagittata Kuntze, 1891, Revis. Gen. P1. 2: 935.

In the recent works (Al-Shehbaz, 2006, 2012b; Al-Shehbaz et al., 2011) this species is named Mostacillastrum sagittatum which, as follows from the above synonymy, is inappropriate due to the illegitimacy of the alleged basionym, Sisymbrium sagittatum Hook. et Arn. and lack of precedence of the actual basionym, Hesperis sagittata, over the heterotypic $S$. volckmannii. Generic placement of a number of species of Mostacillastrum O. E. Schulz is likely to be changed in the future in view of its apparent polyphyly demonstrated by Bartish et al. (2012). It is likely the case of $M$. volckmannii which falls outside the clade containing $M$. stenophyllum (Gillies ex Hook. et Arn.) O. E. Schulz, the generic lectotype. Unless the taxonomy of the group is revised, the proposed name is to be in use for the species.

Noccaea boissieri (Bornm.) D. A. German, comb. nov. $\equiv$ Coluteocarpus reticulatus var. boissieri Bornm., 1906, Beih. Bot. Centralbl. 19(2): 207. $\equiv$ C. boissieri (Bornm.) O. E. Schulz, 1936, in Engler \& Prantl, Nat. Pflanzenfam., ed. 2, 17b: 428. $\equiv$ C. vesicaria subsp. boissieri (Bornm.) Hedge, 1965, Notes Roy. Bot. Gard. Edinburgh 26(2): 181. $\equiv N$. vesicaria subsp. boissieri (Bornm.) Al-Shehbaz, 2014, Harvard Pap. Bot. 19(1): 47.

Among the two principal options of treating this taxon, a viewpoint of Schulz (1936) seems preferable to me having in mind its clear distinctness from $N$. vesicaria (L.) Al-Shehbaz in both vegetative and generative spheres combined with partial allopatry of the two taxa (Hedge in Davis et al., 1965; Al-Shehbaz, 2014).

Odontarrhena caliacrae (Nyár.) D. A. German, comb. nov. $\equiv$ Alyssum caliacrae Nyár., 1926, Bul. Grăd. Bot. Univ. Cluj 6: 92. $\equiv$ Alyssum tortuosum subsp. caliacrae (Nyár.) Stoj. et Stef., 1970, Fl. Reip. Pop. Bulg. 4: 508. EOdontarrhena tortuosa subsp. caliacrae (Nyár.) Španiel, Al-Shehbaz et Marhold, 2015, P1. Syst. Evol. 301(10): 2487.

This combination provides the name available for relavant taxon in the genus Odontarrhena C. A. Mey. ex Ledeb. at the rank of species following the often accepted approach, also by recent authors (e. g., Ančev, 2007). Sometimes it is treated as a subspecies and was recently recognized as $O$. tortuosa subsp. caliacrae (Nyár) Španiel, Al-Shehbaz et Marhold (Španiel et al., 2015: AlyBase 
[http://alysseae.sav.sk/]). However, if the taxon circumscription includes Alyssum caliacrae subsp. prodanii Nyár. (1929) and A. eximium Nyár. (1926), as accepted by the latter authors (http://alysseae.sav. sk/checklists/detail/1529), two other names have precedence at the rank of subspecies and the proper name then would be "O. tortuosa subsp. eximia" in accordance with the priority established by the combination A. tortuosum subsp. eximium (Nyár.) Nyár., 1928, Bul. Grăd. Bot. Univ. Cluj 7: 134.

Rorippa tsaratananae (Jonsell) D. A. German, comb. et stat. nov. $\equiv R$. laurentii subsp. tsaratananae Jonsell, 1979, Bot. Not. 132: 535.

Although vicarious distribution pattern of $R$. laurentii Jonsell s. str. and subsp. tsaratananae emphasized in the protologue of the latter is one of the main traditional arguments (Meilke, 1957; Hawkes, 1963) favouring relevant rank in similar cases, morphological distinctness between the two taxa (simple vs. compound leaves, etc.: Jonsell, 1979; P!) seems to be too serious to keep them conspecific. Generic placement of species assigned to morphologically peculiar Nasturtium sect. Ceriosperma O. E. Schulz [三Ceriosperma (O. E. Schulz) Greuter et Burdet], to which R. laurentii s. 1. was informally attributed (Jonsell, 1. c.), needs further elucidation and it was since long time suspected that this group of species might eventually be recognized as a separate genus (Garnock-Jones, 1978). Available molecular data (Mitchell, Heenen, 2000; Bleeker et al., 2002), especially from nuclear markers, are too scarce yet to make sound conclusions though previously suggested heterogeneity of the group (Jonsell, 1. c.) appears to get support (Bleeker et al., 1. c.) even after the exclusion of $R$. macrocarpa (Boiss.) Mouterde [ $\equiv N$. macrocarpum Boiss.] from Rorippa Scop. and its transfer to Barbarea W. T. Aiton by Al-Shehbaz and Jacquemoud (2000). However, as a result of typification of Ceriosperma by this species (Greuter et al., 1993), most deviating from others assigned by Schulz (1933) to Nasturtium sect. Ceriosperma both geographically and morphologically, the name became synonymous with Barbarea and it is no more applicable to the rest of the group. Thus, retention of $R$. tsaratananae in Rorippa as originally assigned is the most reasonable taxonomic option unless precise phylogenetic position of the species is clarified.

\section{New synonyms}

Barbarea ketzkhovelii Mardal., 1977, Bot. Zhurn. (Moscow \& Leningrad) 62(9): 1300. $\equiv$
Barbamine ketzkhovelii (Mardal.) A. P. Khokhr., 1997, Byull. Glavn. Bot. Sada (Moscow) 175: 50.

Typus: "West Georgia. Svaneti range. Watershed of Urashi and Khobi. 3000 m s. a. 1. Slightly mobile porphyritic talus slopes of the glacier circle. 24 VIII 1976. T. Mardaleyshvili” (TBI!, iso - LE!, TBI!).

= Barbamine procumbens A. P. Khokhr., 1997, Byull. Glavn. Bot. Sada (Moscow) 175: 51, syn. nov.

Typus: "Turkey, A-8, prov. Artvin. Karchal (Macahel-su), 1900-3100 m. 11-14 / VIII 1996. A. P. Khokhrjakov, M. T. Mazurenko, G. A. Martynova" (MHA!, iso - MW!).

According to the label notes, A. P. Khokhryakov initially compared his novelty (first annotated as "Barbarea procumbens") with Barbarea minor $\mathrm{K}$. Koch but later correctly found it to be closer to B. ketzkhovelii. From the latter, Barbamine procumbens was said to differ in "usually prostrate (not ascending) stems, cauline leaves truncate or broadly (not narrowly) cuneate at base, and more arcuate siliques" (Khokhryakov, 1997). These defferences do not look reliable, especially in view of the characteristics "caulibus prostratis vel rarius adscendentibus" and "fructus ... incurvati" from the protologue of Barbarea ketzkhovelii (Mardalejschvili, 1977). A study of the material of both taxa (LE!, MHA!, MW!, TBI!, TGM!) clearly confirmed that Barbamine procumbens falls within the range of variation of Barbarea ketzkhovelii and thus cannot be separated from the latter species easily distinguishable from its congeners by subscapose habit. AlShehbaz (2012a) properly synonymized Barbamine A. P. Khokhr. with Barbarea but it remained hitherto unclear whether the type species of the prior genus should be treated as a distinct member of the latter. Establishment of conspecificity of the two taxa also means a new addition to the flora of Turkey.

Unlike on the labels, D. V. Gvianidze is mentioned in the protologue of Barbamine procumbens as the third collector (instead of G. A. Martynova), the date is 11 VIII and the elevation is $2900-3100 \mathrm{~m}$. These discrepancies should be treated as mistakes to be corrected (ICN Art. 9.1, Ex. 2: McNeill et al., 2012) as long as Khokhryakov's material is restricted to the single gathering represented by three specimens (one in MHA and two in MW), two of which are annotated by him as holotypus and isotypus, respectively. One of the isotypes is supplied with additional label where the elevation "2000-3100 m a. s. 1." is mentioned and "Karchal" is replaced by "Karakal Dagi". It looks like somewhat unprecise label data were subsequently corrected in the validating publication. 
Rorippa austriaca (Crantz) Bess., 1822, Enum. P1. Volhyn.: 103. $\equiv$ Nasturtium austriacum Crantz, 1762, Stirp. Austr. 1: 15.

Typus (fide Jonsell, 1968: 150, 163): [Austria], "Nusdorf via" (BP).

= Cochlearia microcarpa DC., 1821, Reg. Veg. Syst. Nat. 2: 362, syn. nov.

Lectotypus (hic designatus): [Ukraine], "Cochlearia an C. armoracia ad Kriwoluka Pallas. h. Wild. ex Steven" (G-DC: G00202144! [http:// www.ville-ge.ch/musinfo/bd/cjb/chg/adetail.php?id $=172301 \&$ base $=$ img\&lang $=$ en]).

Cochlearia microcarpa DC. [non C. microcarpa K. C. Kuan, 1980, Bull. Bot. Lab. N. E. Forest Inst., Harbin 8: 40, nom. illeg. $\equiv$ Yinshania microcarpa Y. H. Zhang, 1987, Acta Phytotax. Sinica 25(3): 211. $\equiv Y$. acutangula subsp. microcarpa (Y. H. Zhang) Al-Shehbaz et al., 1998, Harvard Pap. Bot. 3(1): 83] since the time of its description is being a rather neglected taxon of uncertain affinity. Although its flowers were unknown to Candolle (1821: 362), he assigned the species to Cochlearia sect. Armoracia (G. Gaertn., B. Mey. et Scherb.) DC. assuming the plant to have white petals. This assumption, probably driven by P. S. Pallas' annotation "C. armoracia?", apparently became the main reason impeded Candolle to recognize this plant with "habitus Myagri austriaci" as Rorippa austriaca itself. The type locality designation "Hab. in Sibiria ad Krivoluka" was also misleading because it referred to Asia instead of Europe (West Ukraine). In subsequent, almost exclusively resumptive works where C. microcarpa was included, this geographical characteristics was reduced to just "Sibiria" (e. g., Candolle, 1824: 173; Steudel, 1840: 392; Jackson, 1893: 575). At the same time, both taxonomic treatments and floristic accounts focused on Siberia and/or Ukraine, unless I occasionally overlooked any, completely ignored the name except for Ledebour (1841: 159) who had no opportunity to see any material and could only repeat the data from the primary source.

According to the protologue, the original material of $C$. microcarpa studied by both $C h$. Steven in Willdenow's collection and then by Candolle "in herb. Stev." is probably partly lost or misplaced because it was not located in either B-W (where it was not found yet by Ledebour, i. e., in 1830ths) or $\mathrm{H}$. The only element available for this study and designated here as the lectotype is the fragment (upper part of fruiting branch with several leaves and silicles) of the syntype unambiguously identifyable as Rorippa austriaca which perfectly fits the true geographic origin of the specimen.
Strigosella scorpioides (Bunge) Botsch., 1972, Bot. Zhurn. (Moscow \& Leningrad) 57(9): 1041. $\equiv$ Dontostemon scorpioides Bunge, 1847, Arb. Naturf. Ver. Riga 1(2): 150.

Lectotypus (Rechinger, 1968: 261; German in Al-Shehbaz et al., 2014: 63): [Uzbekistan], "[Um Buchara, 23 März 1842, Alexander Lehmann] Alexanderi Lehmann Reliquiae botanicae. No. 101. Dontostemon scorpioides Bge. Zwishen Agatme und Karagata 14 Apr bei Tiumen-bai 18 Apr, bei Juss-Kuduk 24 April. Steppe um Kuwan-Darja 7 Maj 1842" (LE!, left plant; iso - LE!, P!).

= Torularia karatavica Myrz. et Bajt., 1979, Not. Syst. Herb. Inst. Bot. Acad. Sci. Kazachst. 11: 54. $\equiv$ Neotorularia karatavica (Myrz. et Bajt.) Czer., 1995, Vasc. Pl. Russia \& Adj. States (former USSR): 145 , syn. nov.

Typus: [Kazakhstan], "Jugum Karatau, angustiae Dzholonur. 29 V 1972. P. Myrzakulov" (AA).

It was already mentioned a while ago that the type (or any other materials) of T. karatavica is absent in AA (German, Veselova, 2011). Nothing was found since then, and analysis of the description has been undertaken in an attempt to clarify the identity of this enigmatic species. A set of characters (e. g., annual life cycle, presence of rigid forked trichomes, oblong to obong-lanceolate, entire, shortpetiolate leaves, lax inflorescences, flowering pedicels $1 \mathrm{~mm}$ long, branched-pubescent sepals $3 \mathrm{~mm}$ long, oblong-spatulate pink petals $5-5.5 \mathrm{~mm}$ long, divaricate-ascending, distally coiled, torulose, hispid siliques $3-3.5 \mathrm{~cm} \times 0.8-1 \mathrm{~mm}$, occurrence in intermountain clayey valleys: Myrzakulov, Bajtenov, 1979) apparently excludes any Middle Asian representatives of the family except for the two closely related Strigosella Boiss. species, S. scorpioides and, to a lesser extent, S. brevipes (Bunge) Botsch. As long as entire leaves are normally not characteristic of $S$. brevipes and, besides, its sepals and petals do not exceed 2.5 and $5 \mathrm{~mm}$ long, respectively (Rechinger, 1968; Botschantzev, Bondarenko, 1978; Zhou et al., 2001), this species, with more or less high degree of confidence, can also be ruled out from consideration. As for $S$. scorpioides, despite usually it produces bigger flowers and longer fruits, the values reported for T. karatavica are still within the range of variation of this species which, besides, is characterized by predominantly entire leaves. No other options look plausible, even from among the related species of Strigosella Boiss. or similar-looking representatives of Neotorularia Hedge et J. Léonard. I dare, therefore, to assume that a rather poor specimen of $S$. scorpioides was described as T. karata- 
vica with an admission that otherwise it would be an untypical plant of $S$. brevipes.

Details of curious typification of $S$. scorpioides are provided in Al-Shehbaz et al. (2014).

In general, existance of a desert annual occurring very locally, especially in a relatively easily accessible and rather well-studied floristically region, and known from the single specimen is highly doubtful. In such cases, the probability of a re-description of already known plant is it much higher. Therefore, distinctness of another annual species, Strigosella myrzakulovii Bajt. (Bajtenov, 1983), also described from Karatau based on just one gathering, is under question. As neither the type, nor the isotype (claimed to be in AA and LE, respectively) were located and it is barely possible to connect the description with any species with certainty, the problem stays pending.

Tetracme recurvata Bunge, 1847, Arb. Naturf. Ver. Riga 1(2): 158.

Lectotypus (Rechinger, 1968: 225, "typus"): [Uzbekistan], "No. 122. Tetracme recurvata Bge. Ad Jan-Darja [3 or 4 May 1842] Al. Lehmann" (W: W0032964!).

$=$ T. leptopoda Pachom., 1974, Not. Syst. Herb. Inst. Bot. Acad. Sci. Uzbek. 19: 38, syn. nov.

Typus: [Uzbekistan], "South Bukhara near Termez. 1913. A. Kirichenko" (LE!, iso - LE!).

Tetracme leptopoda was segregated from T. recurvata based on a few gatherings from a small area in southern Uzbekistan (Pachomova, 1974a) characterized by only slightly (instead of strongly) widened fruiting pedicels and long, "5-7(8) vs. 2-4, rarely 6-7 mm”, fruit horns (Pachomova, 1974a, b). Having in mind the great variation in horn length in
T. recurvata, the latter character cannot be taken as reliable. As for pedicels, indeed, in specimens from around Termez (Termiz) they do not thicken soon after anthesis becoming nearly as thick as the fruits but, instead, stay clearly narrower than siliques, a character not seen by me in other specimens of $T$. recurvata from elsewhere. However, no studied plants of T. leptopoda (type, isotype, and paratypes) have fully ripened fruits and thus it is unknown whether pedicels are still narrow by complete fruit maturity. In any case, even if this character holds (and may be justifies a varietal rank), in view of the otherwise overall morphological and ecological similarity of plants from Termez area with other specimens of T. recurvata I do not see the ground to treat them as belonging to another biological species.

Our choice of a rich (12 plants) specimen with precise collection date (30 April 1842) and collector's annotation from Al. A. Bunge's herbarium (P) as lectotype of T. recurvata (German et al., 2006) turned out to be superfluous on account of existence of an earlier and unintended typification by Rechinger (1968). The above cited actual lectotype consists of a single plant collected on 3 or 4 May 1842.

\section{Acknowledgements}

The study was partly supported by the German Research Foundation (Deutsche Forschungsgemeinschaft, DFG) (grant KO2302-13/1). Curators and responsible managers of all mentioned herbaria are sincerely thanked for the opportunity of work with collections. Nomenclatural advicing and help with some literature by Alexander Nikolaevich Sennikov along with valuable comments and assistance in organizing the visits to $\mathrm{G}$ and P by Ihsan Ali AlShehbaz are highly appreciated.

\section{REFERENCES}

Al-Shehbaz I. A. 2006. The genus Sisymbrium in South America, with synopses of the genera Chilocardamum, Mostacillastrum, Neuontobotrys, and Polypsecadium (Brassicaceae). Darwiniana 44(2): 341-358. URL: http://www.jstor.org/stable/23226692

Al-Shehbaz I. A. 2012a. A generic and tribal synopsis of the Brassicaceae (Cruciferae). Taxon 61(5): 931-954. URL: http://www.jstor.org/stable/41679341

Al-Shehbaz I. A. 2012b. Notes on miscellaneous species of the tribe Thelypodieae (Brassicaceae). Harvard Pap. Bot. 17(1): 3-10. DOI: http://dx.doi.org/10.3100/025.017.0102

Al-Shehbaz I. A. 2014. A synopsis of the genus Noccaea (Coluteocarpeae, Brassicaceae). Harvard Pap. Bot. 19(1): 25-51. DOI: 10.3100/hpib.v19iss1.2014.n3

Al-Shehbaz I. A., Jacquemoud F. 2000. Nasturtium macrocarpum Boiss. transferred to Barbarea (Brassicaceae). Candollea 55(1): 201-203. URL: http://www.ville-ge.ch/cjb/publications/cando551/C551_201-203.pdf

Al-Shehbaz I. A., Muñoz-Schick M., Morales V. 2011. The present status of Brassicaceae taxa described by Rodulfo and Federico Philippi. Harvard Pap. Bot. 16(2): 279-291. DOI: http://dx.doi.org/10.3100/0.25.016.0204

Al-Shehbaz I. A., German D. A., Moazzeni H., Mummenhoff K. 2014. Systematics, tribal placements, and synopses of the Malcolmia s. 1. segregates (Brassicaceae). Harvard Pap. Bot. 19(1): 53-71.

DOI: 10.3100/hpib.v19iss1.2014.n4 
Ančev M. 2007. Catalogue of the family Brassicaceae (Cruciferae) in the flora of Bulgaria. Phytol. Balcanica 13(2): 153-178. URL: http://www.bio.bas.bg/ phytolbalcan/PDF/13_2/13_2_04_Ancev.pdf

Bajtenov M. S. 1983. Species novae in Kazachstaniae inventa. Bot. Mat. Gerb. Inst. Bot. Acad. Nauk Kazahhsk. SSR [Not. Syst. Herb. Inst. Bot. Acad. Sci. Kazachst.] 13: 35-37. [In Russian]

Bartish I. V., Ä̈nouche A., Jia D., Bergstrom D., Chown S. L., Winkworth R. C., Hennion F. 2012. Phylogeny and colonization history of Pringlea antiscorbutica (Brassicaceae), an emblematic endemic from the South Indian Ocean Province. Mol. Phylogenet. Evol. 65(2): 748-756. DOI: 10.1016/j.ympev.2012.07.023

Bleeker W., Weber-Sparenberg C., Hurka H. 2002. Chloroplast DNA variation and biogeography in the genus Rorippa Scop. (Brassicaceae). Plant Biol. 4: 104-111. DOI: 10.1055/s-2002-20442

Boczantzeva V. V. 1985. On the genus Pachypterygium (Brassicaceae). Bot. Zhurn. (Moscow \& Leningrad) 69(2): 248-250. [In Russian]

Botschantzev V. P., Bondarenko O. N. 1978. Strigosella Boiss. In: P. N. Ovczinnikov (ed.). Flora Tadzhikskő SSR [Flora of Tajik SSR]. Vol. 5. Leningrad: Nauka. P. 123-129. [In Russian]

Bomble F. W. 2012. Draba subgen. Erophila in Deutschland. Auf dem Weg zu einer natürlicheren Taxonomie. Jahrb. Bochumer Bot. Ver. 3: 39-49. URL: http://www.botanik-bochum.de/publ/OVBBV3_4_Bomble_Erophila.pdf

Buttler K. P., Hand R. 2008. Liste der Gefäßpflanzen Deutschlands. Kochia 1: 1-107.

URL: http://flora-deutschlands.de/Kochia/Band_3/Kochia_Beiheft.pdf

Candolle A.P. de. 1821. Regni vegetabilis systema naturale. Vol. 2. Parisiis: Socii Treuttel et Würtz. [II] + 745 p.

Candolle A.P. de. 1824. Prodromus systematis naturalis regni vegetabilis. Vol. 1. Parisiis: Socii Treuttel et Würtz. $[\mathrm{VI}]+745 \mathrm{p}$.

Davis P. H., Cullen J., Coode M. J. E., Hedge I. C. 1965. Materials for a Flora of Turkey: X. Notes Royal Bot. Gard. Edinburgh 26(2): 165-201.

German D. A. 2008. Six new synonyms in the Central Asian Cruciferae. Nordic J. Bot. 26(1-2): 38-40. DOI: $10.1111 / \mathrm{j} .0107-055 X .2008 .00234 . \mathrm{x}$

German D. A. 2014. New synonyms and combinations in Eurasian Brassicaceae (Cruciferae). Phytotaxa 173(1): 31-40. DOI: http://dx.doi.org/10.11646/phytotaxa.173.1.2

German D. A., Veselova P. V. 2011. Type specimens of names of Brassicaceae (Cruciferae) taxa deposited in the Herbarium of the Institute of Botany and Phytointroduction of Kazakhstan (AA). Bot. Zhurn. (Moscow \& St. Petersburg) 96(10) : 1378-1388. [In Russian]

German D. A., Cherneva O. V., Carré B. 2006. Typification of Cruciferae taxa described by A. A. Bunge from the Middle Asia. Novosti Sist. Vyssh. Rast. [Novit. Syst. Pl. Vasc.] 38: 286-312. [In Russian]

Greuter W., Brummit R. K., Farr E., Kilian N., Kirk P. M., Silva P. C. (eds.). 1993. NCU-3. Names in current use for extant plant genera. Königstein: Koeltz Scientific Books. XXVII + 1464 p. [Regnum Vegetabile, vol. 129].

Garnock-Jones P. J. 1978. Rorippa (Cruciferae, Arabideae) in New Zealand. New Zealand J. Bot. 16(1): 119-122. DOI: $10.1080 / 0028825 X .1978 .10429664$

Hawkes J. G. 1963. The subspecies in flowering plants. Proc. Birmingham Nat. Hist. Philos. Soc. 20(2): 15-21.

Heywood V. H. 1964. Flora Europaea notulae systematicae ad Floram Europaeam spectantes No. 3. Feddes Repert. 69(1): 1-62.

Jackson B. D. 1893. Index Kewensis: an enumeration of the genera and species of flowering plants. Vol. 1. Part 1. Oxford: Clarendon Press. 1268 p.

Jonsell B. 1968. Studies in the North-West European species of Rorippa s. str. Symb. Bot. Upsal. 19(2): 1-222.

Jonsell B. 1976. Some tropical African Cruciferae. Chromosome numbers and taxonomic comments. Bot. Notiser 129(2): 123-130.

Jonsell B. 1979. New taxa of Cruciferae from East Tropical Africa and Madagascar. Bot. Notiser 132(4): 521-535.

Jonsell B. 2000. A new subspecific combination in Erophila (Brassicaceae) from Ethiopia. Nordic J. Bot. 20(2):

201. DOI: $10.1111 / \mathrm{j} .1756-1051.2000 . t b 01569 . \mathrm{x}$

Jordon-Thaden I., Hase I., Al-Shehbaz I. A., Koch M. A. 2010. Molecular phylogeny and systematics of the genus Draba s. 1. (Brassicaceae) and identification of its closest related genera. Mol. Phylogenet. Evol. 55(2): 524-540. DOI: 10.1016/j.ympev.2010.02.012

Kadereit J. W., Albach D. C., Ehrendorfer F., Galbany-Casals M., Garcia-Jacas N., Gehrke B., Kadereit G., Kilian N., Klein J. T., Koch M. A., Kropf M., Oberprieler C., Pirie M. D., Ritz C. M., Röser M., Spalik K., Susanna A., Weigend M., Welk E., Wesche K., Zhang L.-B., Dillenberger M. S. 2016. Which changes are needed to render all genera of the German flora monophyletic? Willdenowia 46(1): 39-91. DOI: http://dx.doi.org/10.3372/wi.46.46105

Kalheber H. 2003. Zur Gliederung von Erophila verna s. 1. mit Merkmalsprüfungen für die in Hessen vorkommenden Arten. Bot. Naturschutz Hessen 16: 39-56.

Khokhryakov A. P. 1997. Some new taxa from Transcaucasus and Turkey. Byull. Glavn. Bot. Sada (Moscow) [Bull. Main Bot. Garden] 175: 49-55. [In Russian] 
Kiefer M., Schmickl R., German D. A., Mandáková T., Lysak M. A., Al-Shehbaz I. A., Franzke A., Mummenhoff K., Stamatakis A., Koch M. A. 2014. BrassiBase: introduction to a novel knowledge database on Brassicaceae evolution. Plant Cell Physiol. 55(1): e3. DOI:10.1093/pcp/pct158

Ledebour C. F. 1841. Flora Rossica sive enumeratio plantarum in totius imperii rossici provinciis europaeis, asiaticis et americanis hucusque observatarum. Vol. 1. P. 1. Stuttgartiae: Sumptibus librariae E. Schweizerbart. [I]-XVI + [1]-240 p.

Mardalejschvili T. K. 1977. New species of the genus Barbarea R. Br. (Brassicaceae) from the subnival belt of Svanetia range (Western Georgia). Bot. Zhurn. (Moscow \& Leningrad) 62 (9): 1299-1300. [In Russian]

Marhold K. 2011. Brassicaceae. In: Euro +Med: Euro+Med PlantBase - the information resource for Euro-Mediterranean plant diversity. URL: http://ww2.bgbm.org/EuroPlusMed [Accessed 29 July 2016].

Moazzeni H., Zarre Sh., Al-Shehbaz I.A., Mummenhoff K. 2007. Seed-coat micro-sculpturing and its systematic application in Isatis (Brassicaceae) and allied genera in Iran. Flora 202(6): 447-454.

DOI: http://dx.doi.org/10.1016/j.flora.2006.10.004

Moazzeni H., Zarre Sh., Al-Shehbaz I.A., Mummenhoff K. 2010. Phylogeny of Isatis (Brassicaceae) and allied genera based on ITS sequences of nuclear ribosomal DNA and morphological characters. Flora 205(5): $337-343$. DOI: http://dx.doi.org/10.1016/j.flora.2009.12.028

McNeill J., Barrie F. R., Buck W. R., Demoulin V., Greuter W., Hawksworth D. L., Herendeen P. S., Knapp S., Marhold K., Prado J., Prud'homme van Reine W. F., Smith G. F., Wiersema J. H., Turland N. J. 2012. International Code of Nomenclature for algae, fungi, and plants (Melbourne Code). Adopted by the Eighteenth International Botanical Congress Melbourne, Australia, July 2011. Königstein: Koeltz Scientific Books. XXX + 208 p. [Regnum Vegetabile, vol. 154].

Meikle R. D. (comp.). 1957. What is the subspecies? Taxon 6(4): 102-105.

Mitchell A. D., Heenan P. B. 2000. Systematic relationships of New Zealand endemic Brassicaceae inferred from nrDNA ITS sequence data. Syst. Bot. 25(1): 98-105. DOI: http://dx.doi.org/10.2307/2666676

Myrzakulov P. M., Bajtenov M. S. 1979. Species nova Torulariae (Coss.) O. E. Schulz e Karatau. Bot. Mat. Gerb. Inst. Bot. Acad. Nauk Kazahhsk. SSR [Not. Syst. Herb. Inst. Bot. Acad. Sci. Kazachst.] 11: 54-55. [In Russian]

Pachomova M. G. 1974a. Species novae familiae Cruciferae ex Asia Media. Bot. Mat. Gerb. Inst. Bot. Acad. Nauk Uzbek. SSR [Not. Syst. Herb. Inst. Bot. Acad. Sci. Uzbek.] 19: 34-49. [In Russian]

Pachomova M. G. 1974b. Tetracme Bunge. In: A. I. Vvedensky, M. G. Pachomova (eds.). Opredelitel' rasteniy Sredney Asii [Conspectus florae Asiae Mediae]. Vol. 4. Tashkent: FAN. P. 141-144. [In Russian]

Raab-Straube E. von, Raus Th. (eds.). 2014. Euro+Med-Checklist notulae, 3 [Notulae ad floram euro-mediterraneam pertinentes 32]. Willdenowia 44(2): 287-299. DOI: http://dx.doi.org/10.3372/wi.44.44211

Rechinger K. H. 1968. Tribus Matthioleae. Tribus Hesperideae. In: I. C. Hedge, K. H. Rechinger (eds.). Flora Iranica. Vol. 57. Graz: Academische Druck- u. Verlagsanstalt. P. 219-250, 251-308.

Schulz O. E. 1933. Kurze Notizen über neue Gattungen, Sektionen und Arten der Cruciferen. Bot. Jahrb. Syst. 66: 91-102.

Schulz O. E. 1936. Cruciferae. In: A. Engler, H. Harms (eds.). Die natürlichen Pflanzenfamilien. Vol. 17B. Leipzig: Verlag von Wilhelm Englemann. S. 227-658.

Schultze-Motel W., Markgraf F., Hörhammer L., Marzell H., Oberdorfer E., Straka H., Wannenmacher R. 1986. Gustav Hegi: Illustrierte Flora von Milleleuropa. Aufl. 3. Bd. 4. Angiospermae: Dicotyledones 2(1). Berlin \& Hamburg: Verlag Paul Parey. 595 S.

Sebald O. 1969. Beitrag zur Floristik Äthiopiens (Piperaceae - Leguminosae). Stuttgarter Beitr. Naturk. 206: $1-37$.

Španiel S., Kempa M., Salmerón-Sánchez E., Fuertes-Aguilar J., Mota J. F., Al-Shehbaz I. A., German D. A., Olšavská K., Šingliarová B., Zozomová-Lihová J., Marhold K. 2015. AlyBase - database of names, chromosome numbers, and ploidy levels of Alysseae, with new generic concept of the tribe. Plant Syst. Evol. 301(10): $2463-2491$. DOI: $10.1007 / \mathrm{s} 00606-015-1257-3$

Steudel E. G. 1840. Nomenclator botanicus. Ed. 2. Vol. 1. Stuttgartiae et Tubingae: Typis et Sumptibus I. G. Cottae. $852 \mathrm{p}$.

Walters S. M. 1993. Erophila DC. In: T. G. Tutin, N. A. Burges, A. O. Chater, J. R. Edmondson, V. H. Heywood, D. M. Moore, D. H. Valentine, S. M. Walters, D. A. Webb (eds.). Flora Europaea. Ed. 2. Vol. 1. Psilotaceae to Platanaceae. Cambridge: Cambridge University Press. P. 377-378.

Zhou T.-Y., Lu L.-L., Yang G. \& Al-Shehbaz I. A. 2001. Brassicaceae (Cruciferae). In: Z.-G. Wu, P. H. Raven (eds.). Flora of China. Vol. 8 (Brassicaceae through Saxifragaceae). Beijing: Science Press \& St. Louis: Missouri Botanical Garden Press. P. 1-193. 